\title{
From Riot to Revolt: Asbury Park in July 1970
}

\section{By Daniel Weeks ${ }^{1}$}

\section{DOI: http://dx.doi.org/10.14713/njs.v2i2.49}

This paper investigates the civil unrest that rocked the New Jersey resort city of Asbury Park for four days in July 1970. It focuses particularly on how various participants and the media represented the violent events in the West Side of the city. These representations, which were publicized in the Asbury Park Press, the New York Times, and elsewhere, demonstrate two interrelated dynamics. First, that in attempting to characterize the events in Asbury Park-either as a criminal riot or justifiable revolt-participants on all sides resorted to well-worn stereotypes, and second, that these stereotypes, once publicized in the media, began to shape events in the city in consequential ways. This study also demonstrates that the civil unrest moved through several phases-from a teenage "rock and bottle festival" to a true revolt against discrimination, segregation, and the general conditions of the ghetto.

In a last attempt to hold their ground, the youths on the street hurled bottles, bricks, and firebombs at the advancing line of police. In response, gunfire rang out along the avenue, and twenty-two-year-old Harold Suggs turned into an alley to avoid it. In the confusion, he saw his friend Herbert Gaines, just seventeen, suddenly clutch his leg. The blood came then in a torrent as Gaines stumbled into the alley and collapsed on the sidewalk. ${ }^{2}$

\footnotetext{
${ }^{1}$ The author would like to thank Deborah Gray White and the graduate students in the African American History Seminar at Rutgers University for their helpful critical comments and research advice. Thanks are also due to Roger Wilkins for his comments when this paper was presented at The Long, Hot Summers in Retrospect II, a joint conference of the New Jersey Historical Society and the Institute for Ethnicity, Culture, and the Modern Experience, at Rutgers Law School, Newark, N.J., 6 October 2007.

${ }^{2}$ Suggs, who lived in the neighborhood, was a journalism student at Murray State University. Armed with a camera, he joined the crowds gathering on Springwood Avenue on Tuesday afternoon in the hope of taking photos that he might sell to news organizations. Harold V. Suggs, "Student Describes Battle of Tuesday," Asbury Park Evening Press, 9 July 1970.
} 
That same day, the widow Margaret Hayes watched the thick smoke that had been billowing for three days from the buildings across the street from her residence and listened to the shouting and gunfire. She began to wonder if she would make it through alive. The heavy footsteps of angry young men hammering up and down the staircase outside her apartment frightened her. "I'm a nervous wreck," she told a reporter. "I only have one life and I'm trying to save it. Thanks be, I don't have any children to be in this mess." 3

Unlike the Widow Hayes, Mrs. Henry Hayes did have a teenage son who returned home that night with wounds from shotgun pellets in his arm and leg. Though shocked, she was not in sympathy with his cause. "Our boy is very hostile," she told the papers. "He has lots of hostility to white people. I'm telling you this because I'm so ashamed because I can't see any cause for this. I'm ashamed to see the brutality of my own people."4 Others, though, blamed the police. “This, I know, is supposed to be their job," said one neighborhood resident. "But they come in mad. I heard they even shot a little kid out in his yard. This is the way the white man acts down south." 5

In all of these ways, the long, hot summer had finally come to the resort city of Asbury Park, New Jersey, which in July 1970 was rocked by four days of rioting. The event was serious enough to receive extensive coverage, not only in the local papers, but also in the New York Times and on the major television networks. The governor sent in 150 state troopers and in the aftermath asked President Nixon to declare the city a disaster area. In the end, 180 people had been injured, and the city had suffered more than $\$ 4$ million in damages. ${ }^{6}$

\footnotetext{
${ }^{3}$ Adrian Keffern, “Police Behavior: Opinions Differ," Asbury Park Evening Press, 9 July 1970.

${ }^{4}$ Ibid.

${ }^{5}$ Ibid.

6 "Second Week of July in Retrospect," Asbury Park Evening Press, 12 July 1970; "Trouble Across the Tracks," Time, 20 July 1970, http://www.time.com/magazine/article/0,9171,877071,00.html; "Last of the Troopers Leave Asbury Park," New York Times, 14 July 1970; Walter H. Waggoner, "U.S. Aid Sought for Asbury Park," New York
} 
This study will investigate the "troubles" in Asbury Park, as city residents sometimes refer to them, with a particular focus on how participants represented the events of that July. The statements that various officials, community leaders, and participants made to the newspapers demonstrate two interrelated dynamics. First, they often resorted to well-worn stereotypes in order to try to define what was happening. And second, and perhaps more importantly, leaders of the black community in particular used their access to the media to shape the narrative of events in consequential ways, transforming the disorder on the streets from riot to revolt.

A second purpose of this study is to fill an historical gap. To date, the civil unrest in Asbury Park has received little scholarly notice. ${ }^{7}$ Some of the reasons for this neglect are obvious. Next to Los Angeles, Detroit, or Newark, where major "race riots" took place in the 1960s, Asbury Park is a small town. Then, too, in Asbury no one died, and historians, who are never immune to the culture in which they live, tend to measure the importance of civil unrest in terms of the death toll. But that is not to say what happened in Asbury is unimportant, particularly to the history of the city itself and to the history of New Jersey. Beyond these considerations, the events in Asbury Park should be remembered as part of what has been called the "Black Revolt" of the 1960 s. $^{8}$

Times, 10 July 1970; Daniel Wolff, $4^{\text {th }}$ of July, Asbury Park: A History of the Promised Land (New York: Bloomsbury, 2005), 187.

${ }^{7}$ Perhaps the best treatment of the riots to appear heretofore is in Wolff's $4^{\text {th }}$ of July, Asbury Park: A History of the Promised Land. But Wolff's book, which has the virtue of employing much original research, is chiefly concerned with the history of Asbury Park as a whole and its connection to the music of Bruce Springsteen. The Asbury Park riots are also summarized briefly by Elizabeth M. Webb in "Asbury Park (New Jersey) Riot of 1970," in Race and Racism in the United States, ed. Charles Gallagher and Charles D. Lippard (Santa Barbara, Calif.: Greenwood, 2014), 79-80.

${ }^{8}$ On the severity of Watts, Detroit, and Newark, see Paul A. Gilje, Rioting in America (Bloomington, Ind.: Indiana University Press, 1996), 160. Government-sponsored commission reports, essay collections, and full monographs have been written for the Los Angeles, Detroit, and Newark riots. Among the more notable are: Nathan Cohen, ed. The Los Angeles Riots: A Socio-Psychological Study (New York: Praeger, 1970); Jerry Cohen and William S. Murphy, Burn, Baby, Burn! The Los Angeles Race Riot, August, 1965 (New York: Dutton, 1966); Robert Conot, Rivers of Blood, Years of Darkness: The Unforgettable Classic Account of the Watts Riot (New York: Bantam Books, 1968); California Governor's Commission on the Los Angeles Riot, McCone Commission Report: Complete and Unabridged (Los Angeles, Calif.: 1965); Gerald Horne, Fire this Time: The Watts Uprising and the 1960s 
The history of the Black Revolt is in itself a matter of some scholarly contention, and to include the civil unrest in Asbury in the historiography of the revolt automatically involves this study in a complex debate over terminology. Historians, reflecting the divisions that were contemporaneous with the events of the 1960s and 1970s, cannot agree on how the civil unrest of that period ought to be categorized. Were these instances of disorder "riots," a word that carries a pejorative meaning connected to criminality, or were they part of a "revolt" against systemic injustice? It is hardly possible, though, to come to any understanding of an incidence of rioting or urban revolt without an analysis of the social, political, and economic conditions of the community in which the trouble erupts. In this regard, Asbury Park provides a model for understanding the connection between urban upheaval, declining economic conditions, discrimination, segregation, and the relative political influence of whites and blacks in a segregated community. ${ }^{9}$

As the historian George Rudé noted more than forty years ago, the motivations of any crowd are never easily discovered. ${ }^{10}$ But while we must recognize the diversity of individual motivations, it is nevertheless true that the participants on each side in any riot, revolt, uprising, or street action begin to define the events in terms of a simple binary with the rioters on one side and the forces of order on the other. Each side then begins to use stereotypes in order to gain the

(Charlottesville, Va.: University of Virginia Press, 1995); Sidney Fine, Violence in the Model City: The Cavanaugh Administration, Race Relations, and the Detroit Riot of 1967 (Ann Arbor, Mich.: The University of Michigan Press, 1989); Hubert Locke, The Detroit Riot of 1967 (Detroit, Mich.: Wayne State University Press, 1967); Van Gordon Sauter and Burleigh Hines, Nightmare in Detroit: A Rebellion and Its Victims (Chicago: Regnery, 1968); Tom Hayden, Rebellion in Newark: Official Violence and the Ghetto Response (New York: Random House, 1967); New Jersey Governor's Select Commission on Civil Disorder, Report for Action: An Investigation into the Causes and Events of the 1967 Newark Race Riots (New York: Lemma Publishing, 1972).

${ }^{9}$ For a discussion of how authorities in the 1960s tended to define "riot," see Kurt Lang and Gladys Engel Lang, "Racial Disturbance as Collective Protest" in The Black Revolt: The Civil Rights Movement, Ghetto Uprisings, and Separatism, James A. Geschwender, ed. (Englewood Cliffs, N.J.: Prentice-Hall, 1971), 257. For the disagreement among scholars on how to characterize the civil unrest of the 1960s and 1970s, see Michael W. Flamm, Law and Order: Street Crime, Civil Unrest, and the Crisis of Liberalism in the 1960s (New York: Columbia University Press, 2005), 220 n. 1, and Gilje, Rioting in America, 4-6.

${ }^{10}$ George Rudé, The Crowd in History, 1730-1848 (New York: Wiley \& Sons, 1964), 9. 
moral high ground. The police and various government officials tend to categorize the rioters or rebels as a "rabble" or "mob" to emphasize the criminality of their conduct. According to Rudé, an adjunct to this conservative generalization is the claim that "the mob in question, having no ideas or honorable impulses of its own, is liable to be presented as the 'passive' instrument of outside agents." 11 In cases where the authorities succeed in so defining the crowd, the event will be deemed a "riot" in the criminal sense, requiring the decisive use of police force. ${ }^{12}$

The participants themselves and those who sympathize with them, in order to justify the violent street action, emphasize the injustice, not only of the forces of order, but of the order itself. In this context, the rioters are elevated to rebels against the forces and structures of injustice. Seen in this light they become "patriots," "democrats," and "freedom fighters," and the event might then be deemed a "revolt." 13

In their effort to categorize each other and put their stamp on the events in the streets, government officials on one side and the crowd on the other hope to influence how the media and perhaps how historians will ultimately define the disturbances. As Jill A. Edy has noted, negotiations over meaning begin in the media, which tends to rely on official sources. But, she adds, the weight of official statements normally declines as the events recede. As Edy explains, “Once an event is past, reporters' dependence on officials for timely information drops sharply, changing the relationships between these actors." The media's increased authority to reassess official comment often first appears in editorial comment, as in the case of Asbury Park. By contrast, once officials go out of office, their ability to influence the story diminishes. The media

\footnotetext{
${ }^{11}$ Ibid., 7-8.

12 Ibid., 6-9.

${ }^{13}$ Rudé took note of these stereotypes in 1964 . His concern, though, was that historians applied them. Here we see that the participants themselves resorted to this kind of stereotyping in order to gain political advantage. See Rudé, The Crowd in History, 6-9. For adaptations of Rudé's theory to the Black Revolt, see Robert M. Fogelson, Violence as Protest: A Study of Riots and Ghettos (Garden City, N.Y.: Doubleday \& Co., 1971), 27-51, and James W. Button, Black Violence: Political Impact of the 1960s Riots (Princeton, N.J.: Princeton University Press, 1978), 4-9.
} 
then achieves full authority over the story until the pastness of the event and its importance draw scholarly attention. ${ }^{14}$

As Michael W. Flamm has noted, in the attempt to categorize the street actions of the 1960s and 1970s, "riot," which has "a precise legal meaning as well as a symbolic significance," is "the most common term." But because it carries a pejorative connotation, scholars have searched for other terms. "White scholars and officials," Flamm writes, prefer "civil unrest," while African-American scholars favor "rebellion" or "uprising." Although scholarship has not heretofore attempted to define the disorders in Asbury Park, popular references to them reflect a similar division. People who live in the communities near Asbury Park most commonly refer to the disorders as "riots," while those who live in the neighborhood where the events took place tend to call them "the troubles" - a milder reference. ${ }^{15}$ Scholarly analysis of the events in Asbury Park, however, leads to the question of whether they might best be characterized as a "revolt."

One further reason for scholarly neglect of the unrest in Asbury Park is likely the fuzziness of its cause. The initial reason people on the West Side of the city took to the streets cannot be easily related to any uplifting social or political purpose. This might make Asbury something of a special case but for the fact that riots are by their nature chaotic. But chaotic though they may be, the causes of other riots and revolts seem easier to ascertain. The riots that broke out in U.S. cities in response to the assassination of Martin Luther King, Jr., for instance, have an easily identifiable cause. So does the Newark riot of 1967, where the police beating of a black cab driver triggered the protest and riot. While the incident itself may seem too minor to

\footnotetext{
${ }^{14}$ Jill A. Edy, Troubled Pasts: News and the Collective Memory of Social Unrest (Philadelphia: Temple University Press, 2006), 5-8.

${ }^{15}$ Flamm, Law and Order, $220 \mathrm{n} 1$. Three men whom the author interviewed in the spring of 2007 who lived in the neighborhood during July 1970 referred to the events as "the troubles." See n. 17.
} 
justify the level of violence that ensued, when the beating is seen as a symbol, a proverbial "last straw" in a series of police injustices toward the black community in Newark and more generally across the country, the outrage of the crowd is suddenly understandable. ${ }^{16}$

But in Asbury Park there was no trouble after Dr. King's murder, nor was there any trigger or last straw — such as a provocative instance of police brutality - that brought on the disorder. ${ }^{17}$ In Asbury, the trouble started a little before midnight on the Fourth of July when groups of African-American teens began throwing rocks and bottles at each other while "hanging out" on Springwood Avenue near Cuba's bar. Such "rock and bottle festivals," as longtime city resident Gilbert Reed refers to them, were not uncommon. A similar incident had occurred at a youth basketball league game in the neighboring town of Neptune just a week earlier, but in that instance the police easily dispersed the crowd. On Springwood, though, the disorderly conduct became more serious after a bottle struck a car stopped at a traffic light near the bar. The car may have been struck accidentally, but the youths soon began pelting passing cars with rocks and bottles and, according to one witness, even dumped the contents of a garbage can into a convertible. At this early stage in the mayhem, the youths seem to have attacked cars without regard to whether the occupants were black or white. ${ }^{18}$

\footnotetext{
16 “The 'Hot Summer' Comes to Asbury Park," New York Times, 12 July 1970; Wolff, $4^{\text {th }}$ of July, 180-81. The rumor that the African-American cabdriver had died while in police custody seems to have inflamed the crowd in the case of Newark. See Report of The National Advisory Commission on Civil Disorders, also known as the Kerner Commission Report (Washington, D.C.: U.S. Government Printing Office, 1968), 30-34. As Terry Ann Knopf has noted, rumors often are a key factor in the outbreak of riots, though they seem to have played little if any role in Asbury Park. See her book Rumors, Race, and Riots (New Brunswick, N.J.: Transaction Books, 1975), 109, 117, 145, 151; Gilje, Rioting in America, 157-58.

${ }^{17}$ Although at least one scholar who has studied the Asbury Park "riots" has said that one eyewitness, decades after the event, asserted to him that an incident of police brutality did spark the disorders, there is no contemporary mention of such an incident. Spokespeople for the African-American community in 1970 were not shy about speaking to the press about police abuse and brutality during the unrest, and it seems very unlikely that they would not have mentioned such an incident to the media had one occurred. The scholar in question was not able to locate any note of his conversation with the witness.

${ }_{18}$ Wolff, $4^{\text {th }}$ of July, 168, 180-81; James McCormick and John Wheeling, "Disorders Wrack City; Mayor Orders Curfew," Asbury Park Evening Press, 6 July 1970. This reconstruction of the initial events on Saturday night, July 4, combines the recollections of Donald Hammary as quoted in Wolff's $4^{\text {th }}$ of July in Asbury Park with the
} 
The timing and nature of the police response very likely led to the subsequent intensification of the disorder. According to Donald Hammary, a representative of the Monmouth Community Action Program and an eyewitness, two Asbury patrolmen arrived to disperse the crowd. But their presence only caused it to grow. The crowd largely ignored the order of the officers to disperse. Hammary claims the patrolmen then used a corner pay phone to call for backup as the crowd began to surround them. When no backup arrived, the crowd began to menace the officers, both of whom were black, to the point where one pulled his revolver. At this point, two black teen dances let out, one from the community center, the other from the nearby Catholic Church, swelling the crowd. ${ }^{19}$

David Parreott, a police detective in 1970, later claimed that the segregation of the police department itself may have contributed to the initial outbreak of looting. Parreott told author Daniel Wolff that white police considered the West Side to be the black officers' turf and would not respond to calls from the vicinity of Springwood. There were twelve black officers on the forty-eight-man Asbury force, but it is unclear how many were on duty at midnight on the Fourth. Suffice it to say, when no backup arrived, it was obvious to all that the crowd was in control. Hammary recalled that someone shouted, "Get rid of them black pigs! Get them out of

recollections of long-time city residents Gilbert Reed, George Corbin, and Larry Tilton, given in private communication with the author. In 1970, Hammary was a representative of the Monmouth Community Action Program in Asbury Park. He told Wolff, who interviewed him in 1997, that on the night of July 4, 1970, he had walked over to Cuba's after closing up his father's billiard hall on Springwood Avenue. Reed, who was twenty-two years old in July 1970, had just returned home to Asbury Park from service in the Air Force when the riots broke out. He joined the Asbury Park Police Department the week after the riots. Corbin was himself a fourteen-year-old. Their testimony essentially corroborates what Hammary told Wolff, though they do not claim eyewitness knowledge. Tilton, who was twelve in 1970, remembers his father responding to the earlier rock-and-bottle fight in Neptune. Police records would be useful in reconstructing these events, but the records of the Asbury Park Police were unfortunately destroyed in a flood in the mid-1970s. The author also requested access to state police records only to be told that New Jersey is a "closed records state" and that the reports of the Asbury Park riots remain closed to the public.

${ }^{19}$ Wolff, following Hammary's account, suggests that the patrolmen arrived in a police cruiser, but this would not explain why they used a pay phone to call for backup. Why wouldn't they have used the radio in the squad car? Hammary also says the two patrolmen fled on foot, which would seem unlikely if they had arrived in a squad car. See Wolff, $4^{\text {th }}$ of July, 180-81. As Rudé notes, the character of the response of the authorities to any crowd action is critical in understanding an event of this kind. See Rudé, The Crowd in History, 11. 
here!" at which point the crowd began to surge forward. Both patrolmen quickly fled on foot. With the forces of order dispersed, people began to kick in the windows of businesses. ${ }^{20}$

Police Chief Thomas S. Smith soon called out the entire police force, which was able to bring matters under control. No injuries were reported, and Smith later told the Asbury Park Evening Press that property damage amounted to little more than nine broken windows. ${ }^{21}$

The disturbances on the Fourth of July were not remarkable enough to elicit press coverage. But the actions of an emboldened crowd in the city's West Side on July 5 would garner attention from the local media. After nightfall on that day, crowds of teenagers once again assembled on Springwood Avenue. Unlike the night before, the crowd seemed more organized, more violent, and much more difficult to disperse-all of which suggests that the teens had learned the weaknesses of the local police. As Chief Smith explained to the Press, "My men would move in, disperse a large group of about 200 people, they would separate, move a couple of blocks and form up again."22

Trouble erupted at about 11 p.m. as teens began breaking windows. By 12:20 a.m. about seventy-five teens had made their way west into the neighboring municipality of Neptune where

\footnotetext{
${ }^{20}$ Wolff, $4^{\text {th }}$ of July, 181. It is difficult to assess the meaning of the "turf" of black officers in Asbury Park. Before the 1960s, black police in many cities were often assigned only to black neighborhoods to prevent them from having to arrest whites, which might outrage white sensibilities. Black police understandably claimed that assigning black officers only to all-black neighborhoods relegated them to second-class status in the department. On the other hand, in 1968, Mayor Carl Stokes of Cleveland, during a period of racial tension, removed all white officers from black neighborhoods in order to prevent any outrage to black sensibilities. Then, too, by 1970, many cities began to assign only black officers to black neighborhood to meet the demands of the black communities for community control of the police. Robert M. Fogelson sees the demand for community control growing out of the Black Power and Black Nationalist movements of the late 1960s. W. Marvin Dulaney notes that the Black Power movement also radicalized black police officers in the 1960s. These officers also called for black policing of black communities. For the police issue, see Dulaney, Black Police in America (Bloomington, Ind.: Indiana University Press, 1996), 64, 68-69, 73, 79. For the connection between community control and Black Nationalism, see Fogelson, Violence as Protest, 136, 170-71, and Gary Gerstle, American Crucible: Race and Nation in the Twentieth Century (Princeton, N.J.: Princeton University Press, 2001), 295-303. For a contemporaneous account of the connection of community control to Black Power, see Stokely Carmichael and Charles V. Hamilton, Black Power: The Politics of Liberation in America (New York: Random House, 1967), 164-77.

${ }^{21}$ Wolff, $4^{\text {th }}$ of July, 181; McCormick and Wheeling, "Disorders Wrack City," Asbury Park Evening Press, 6 July 1970.

${ }^{22}$ McCormick and Wheeling, "Disorders Wrack City” Asbury Park Evening Press, 6 July 1970.
} 
they smashed the windows of the Neptune Diner on Route 35. According to the Press, eight teens entered the diner and took about $\$ 600$ from the cash register but did not harm or accost the patrons. Asbury Park Mayor Joseph F. Mattice declared a state of emergency at 3 a.m. and called in about a hundred reinforcements from neighboring police forces. By 4 a.m., the police were able to report that the rioting was under control. An hour later, the police from neighboring towns were sent home. By 6 a.m., the trouble had largely subsided except for sporadic windowbreaking. $^{23}$

During Sunday night's disturbances, which Smith characterized as "out of control" until 4 a.m., six policemen were injured, seventy-five percent of the businesses on Springwood Avenue were damaged, and many were looted. The rioters had set a small fire at the local Acme Market and several others in trash baskets throughout the West Side. Several police cars were damaged, and two false fire alarms were sent it. In all, police arrested twenty persons. ${ }^{24}$

Press coverage allowed various spokespeople to begin to characterize events in ways that would have a significant impact on what subsequently occurred. The Rev. Verner R. Matthews, pastor of the Second Baptist Church and a member of the board of trustees of the West Side Community Center, attributed the trouble to the general conditions on the West Side, a neighborhood the New York Times would later call a "ghetto." "When people see the conditions of the streets - bottles, dope addicts, and vagrants - they do not want to do business with the shops bordering on this mess," Matthews told the Press. He accused town officials of neglecting the black community. "The political leaders are only interested in the main source of revenue for the city—the Boardwalk," he said. ${ }^{25}$

\footnotetext{
${ }^{23}$ McCormick and Wheeling, "Disorders Wrack City," Asbury Park Evening Press, 6 July 1970; "Second Week of July in Retrospect," Asbury Park Evening Press, 12 July 1970.

${ }^{24}$ Ibid.

${ }^{25}$ McCormick and Wheeling, "Disorders Wrack City,” Asbury Park Evening Press, 6 July 1970.
} 
Matthews's comments suggest that, given the city fathers' neglect, the outbreak of violence was understandable. But he did not go so far as to justify it. "This rioting and looting only alienates people," he said, "and makes it harder for community leaders to attain the goals of more jobs, better education, and better housing." Ermon K. Jones, the president of the local branch of the NAACP, agreed with Matthews on the issues of jobs and housing but noted that the problems were longstanding and that it had been only a matter of time before violence resulted. But he also cited youth dissatisfaction with the West Side Community Center, of which Matthews was a trustee. Jones told the press that the youth should have been represented on the Center's board of trustees and explained "that their exclusion has caused a sense of noninvolvement." 26

In their comments, Matthews and Jones were astutely using the publicity the disorders occasioned to draw public attention to long-term problems within the black community, problems the largely white municipal government had neglected. It is not clear, though, that the teenagers who began the disorders had these particular grievances in mind when they began throwing rocks at each other on the evening of July 4. That a large number of teens in the West Side were on the streets after 11 p.m. with nothing better to do than throw rocks and bottles at each other may be connected to teenage unemployment in the city and to a general sense of hopelessness. But even if the general conditions on the West Side explain the way in which the teens acted out, they do not explain why. Obviously, the teenagers who came from the dances did have something better to do that evening, though some joined in the mayhem anyway. And it is worth noting that, in a larger context, teenagers in the 1970s-white and black, poor and affluent—often "acted out" against authority, sometimes for social or political causes, sometimes

\footnotetext{
${ }^{26}$ Ibid.
} 
not. The difference was that authorities were more apt to define disorderly conduct on the part of groups of black teens as "rioting," which called for a more determined police response. ${ }^{27}$

The statements of Matthews and Jones were also calculated to link the events in Asbury Park to the series of violent upheavals in U.S. cities that began in New York in 1964 and continued through the early 1970s. Whatever the origin of each of the more than one hundred race-based riots or revolts that took place in America's urban centers in these years, journalists, government officials, activists, militants, and social scientists have seen them as part of a larger movement, which the sociologist James A. Geschwender called "The Black Revolt." In any case, most observers have traced the causes of these revolts or riots to the conditions in the urban ghettos. Grievances included high unemployment or underemployment, low-income jobs, the lack of black-owned businesses, substandard housing, police brutality, too few African Americans on the police force, poor city services, and a lack of representation in municipal government. These grievances, in themselves, thematically connect the upheaval in Asbury Park with the Black Revolt of the late sixties, when the demand for economic rights intersected with a demand for community control of black neighborhoods. Both of these issues arose in Asbury Park and can be seen in the statements of Matthews and Jones. ${ }^{28}$

\footnotetext{
${ }^{27}$ The same edition of the Press that broke the story of the troubles in Asbury also carried a story on the front page reporting the arrest of thirty-eight white youths in the resort community of Seaside Heights on charges ranging from drug possession to disorderly conduct. "38 Arrests Reported by Resort," Asbury Park Evening Press, 6 July 1970; Kurt Lang and Gladys Engel Lang, "Racial Disturbance as Collective Protest" in The Black Revolt, Geschwender, ed., 257.

${ }^{28}$ The periodization for the Black Revolt is a matter of some scholarly contention. Fogelson began his study with the Harlem riot of 1964, which has been more or less the traditional stance. Gerstle also dates the beginning of the Black Revolt from the Harlem riot of 1964, though he includes the urban revolt as part of a larger whole, which he terms "the civil rights revolution" that begins in the early 1960s with the passage of federal civil rights legislation. Gilje, however, argues that the focus on property and ghetto conditions that characterize the unrest of the 1960s can be seen in the Detroit riot of 1943 and in the Harlem riots of 1935 and 1943, which suggests an early starting point for the "Ghetto Revolts," as they are sometimes called. See Gilje, Rioting in America, 156-57; Gerstle, American Crucible, 301; Fogelson, Violence as Protest, 1. On the economic demands of urban blacks during the 1960s, the conditions of the ghettos, and the issue of community control, see Stanley Lieberson and Arnold R. Silverman, "The Precipitants and Underlying Conditions of Race Riots," in The Black Revolt, Geschwender, ed., 325-29; Gerstle, American Crucible, 278-79, 301-303; Fogelson, Violence as Protest, 136, 170-71; Steven F. Lawson, Civil Rights
} 
The root cause of all of these problems was segregation, which essentially cordoned African-American communities off from the rest of society, creating conditions for general neglect. As Douglas S. Massey and Nancy A. Denton have noted, segregation is a system of "institutional practices, private behaviors, and public policies" that whites used "to contain growing urban black populations." The 1968 Kerner Commission Report recognized the connection between segregation, poverty, and civil disorder, but as Massey and Denton argue, scholars since the 1970s have given short shrift to the pervasive and systemic nature of segregation and have tended to locate the cause of black poverty and crime in a "culture of poverty" endemic to the black community. ${ }^{29}$ Massey and Denton conclude, however, that the culture of poverty arises, not from any factors particular to African Americans per se, but from the externally imposed condition of segregation, which built decay, crime, and social disorder into the community. ${ }^{30}$ Civil unrest stemming from these ghetto conditions is a form of widespread protest against segregation and discrimination.

The comments of Matthews and Jones pointed to fundamental truths about the segregated city of Asbury Park and conditions in the West Side. That slum conditions in the West Side were decades old can be seen from a 1945 state report, which noted that nearly a third of the dwelling units in the black section of town were substandard. The Urban Colored Population Commission cited an Asbury Park Housing Authority survey from 1938, which described the West Side as "definitely blighted." Although World War II significantly increased the black population in the city from 3,513 in 1940 to more than 4,300 by 1945 , the city, state, and federal governments did little to improve housing. Between 1941 and 1952, the local housing authority,

Crossroads: Nation, Community, and the Black Freedom Struggle (Lexington, Ky.: University of Kentucky Press, 2003), 4, 7-11.

${ }^{29}$ Douglas S. Massey and Nancy A. Denton, American Apartheid: Segregation and the Making of the Underclass (Cambridge, Mass.: Harvard University Press, 1993), 3-11; Kerner Commission Report, 1.

${ }^{30}$ Massey and Denton, American Apartheid, 13. 
with federal funds, built three public housing projects, providing just 397 units. But by 1970 nothing more had been done. ${ }^{31}$

The creation of the ghetto and its attendant neglect were the result of pervasive segregation in Central New Jersey. Although discrimination in housing was not permitted under federal statute after 1968, de facto segregation was the result of discriminatory real-estate practices dating back a hundred years. As a result, the African-American populations in Monmouth County were concentrated in particular neighborhoods of urban areas. The outlying suburban areas were almost exclusively white. ${ }^{32}$

While World War II brought increased economic opportunities for blacks in Monmouth County, it did little to break down the segregation in the county generally or in Asbury Park in particular. The 1945 report notes that Asbury became a military training center during the war. The federal government took over the local YMCA, the Convention Hall, and other buildings to use as training facilities, and many blacks who came to the city for training subsequently stayed. Others came to work on federal construction projects nearby. The report also notes that "large groups of students from the advanced classes of Negro schools and colleges of the Southern states were brought to this area for employment and training courses in the Signal Corps laboratories [at Fort Monmouth]. Negro graduates of high schools and colleges with a background of Chemistry and Physics were attracted to the area and found employment." 33

\footnotetext{
${ }^{31}$ Joseph Clarke, Roger W. Tucker, A. Kenneth Worde, and Joseph P. Bowser, Migration and Housing Among the Negro Population of Asbury Park, New Jersey, for the Urban Colored Population Commission, State of New Jersey, 1941 [1945], 5, 8-9, 19; U.S. Department of Housing and Urban Development, Capital Fund Public Housing Authority Report, Development Breakdown Report 2006, Asbury Park Housing Authority; A Concise History of Fort Monmouth, New Jersey, and the U.S. Army Communications-Electronics Life Cycle Management Command (Fort Monmouth, N.J.: Office of the Deputy Chief of Staff for Operations and Plans, U.S. Army CommunicationsElectronics Life Cycle Management Command, 2006), 21.

${ }^{32}$ The Fair Housing Act, 42 U.S.C. 3601 et seq.; Clarke, et al., Migration and Housing, 8, 22; Wolff, $4^{\text {th }}$ of July, 37, 44.

${ }^{33}$ Clarke, et al., Migration and Housing, 8, 15-16.
} 
As the report shows, African Americans who came to Asbury during the war were either skilled workers or service personnel, and most were employed in well-paid positions. But regardless of their education, social status, or income, they all generally had to find a place to live within the segregated sections of Asbury Park or other urban centers. The discrimination and racism inherent in real estate and in society generally left no other alternatives. And, in the case of Asbury Park, the area open to African Americans was already long recognized as "blighted." 34

By 1970, Asbury Park's total population had grown from 14,617 in 1940 to about 22,000. The black population had increased to more than 8,000 and was still largely concentrated in the West Side, which the New York Times characterized as "a dilapidated neighborhood . . . virtually isolated from the big resort hotels and the sea." The urban renewal project initiated some twelve years earlier was stalled. By 1970, too, the city was in decline as a resort, though its beaches still attracted about 4,000 people on a summer Saturday or Sunday. In the course of a summer, more than 80,000 tourists visited the town. But the relatively brisk business on the beach translated into few summer jobs for African-American youths. According to the Times, in the summer of 1970 there were only 246 jobs available to West Side teens through the Neighborhood Youth Corp-half the number available the previous year. The Neighborhood Center reported that it had received more than 700 applications from teens for fewer than forty summer positions. The overall unemployment rate among black teens in Asbury was a whopping twenty percent. ${ }^{35}$

What Matthews and Jones had done was to place the violent outburst on the streets into an explanatory frame and connect it to a collective memory of injustice and social unrest that

\footnotetext{
${ }^{34}$ Ibid.

${ }^{35}$ Clarke, et al., Migration and Housing, 6; "The 'Hot Summer' Comes to Asbury Park," New York Times, 12 July 1970; "46 Shot in Rioting at Asbury Park," New York Times," 8 July 1970; "Asbury Park Stores Draw Buyers Again," New York Times, 13 July 1970; Rudy Johnson, "Asbury Park Blacks List 21 Demands, Putting Emphasis on Jobs," New York Times, 8 July 1970.
} 
stretched back at least as far as Watts. Although neither justified what to this point had been little more than vandalism, the context each provided suggested that the troubles on the street were not wholly irrational, but were rather an understandable reaction to systemic injustice. The underlying premise of their argument was that the blame lay in the social and political structure. While such arguments did not justify violence per se, they certainly helped to provide legitimacy to whatever street action might ensue. ${ }^{36}$

After day two of the troubles, the "forces of order" remained circumspect in assigning meaning to the unrest. Mayor Mattice made no statement characterizing the disorder beyond declaring an emergency. Chief Smith said merely that it was "too early for me to try and analyze this disturbance." With the memory of the major civil unrest in U.S. cities throughout the late 1960s fresh in everyone's mind, local officials seemed to be aware that any official statement was likely to heighten tensions. ${ }^{37}$

July 6 dawned quietly. To head off further trouble, the mayor declared a curfew to begin at 6 p.m., but by early afternoon police were reporting "incidents of damage to cars of passersby, fights, and continued harassment of police and white civilians." At 2 p.m., town officials once again called on neighboring communities for police support and, in a significant escalation, called in the state police. A few representatives of the state police had been present on day two of the troubles but only as observers. Now the state troopers would take a direct role. ${ }^{38}$

There was also an escalation of the level of force on the other side. Several small trash fires had been set during the disturbances on the fifth, but now the rioters resorted to widespread, systematic arson. As fires began to spread throughout the West Side, police called in help from

\footnotetext{
${ }^{36}$ For a discussion of the framing of events, see Edy, Troubled Pasts, 8-16.

${ }^{37}$ McCormick and Wheeling, "Disorder Wracks City," Asbury Park Evening Press, 6 July 1970.

${ }^{38}$ McCormick and Wheeling, "Disorders Wrack City," Asbury Park Evening Press, 6 July 1970; John Wheeling,

“State, Local Policemen Guard West Side Ruins," Asbury Park Evening Press, 7 July 1970.
} 
other fire departments. The first fire started about 3 p.m. in the rear of the Capitol Bar on Springwood Avenue. It quickly spread to Fisch's Department Store, one of the largest businesses in the West Side and a significant employer of African Americans. Fisch's had been white-owned since its establishment in 1941, but its sale in June 1970 to another white owner had occasioned protests. The store was looted soon after the deal was announced. At the time, Tony Maples of the local United Black Brotherhood complained, saying, "we want stores in our community to be run by black businessmen."39

Scholars have noted that inner-city blacks who used arson as a form of protest during periods of disorder specifically targeted exploitive white-owned businesses. But whether this was so in the case of Fisch's is far from clear. The original owner, George D. Fisch, told community leaders that no black buyers had come forward to purchase the store. Moreover, the fire that consumed Fisch's seems to have been set at the Capitol Bar and to have spread from there. Then, too, many more black-owned businesses seem to have been looted and burned, including that of Maples. There were exceptions though. The Paramount Paint and Wallpaper Store on Springwood, whose African-American owner posted a sign "Soul Brother-Don't Hit," remained untouched. ${ }^{40}$

The New York Times, which began its coverage on July 6, reported that firefighters and police who attempted to move into the area "were turned back by several hundred angry people." Deputy Police Chief Thomas Flanagan told the Times that Asbury firemen who responded to the alarms on Springwood "were attacked by rock-throwing youths." The firemen fled under the

\footnotetext{
${ }^{39}$ Wheeling, "State, Local Policemen Guard West Side Ruins," Asbury Park Evening Press, 7 July 1970; "Fire is the Climax of Fisch's Troubles," Asbury Park Evening Press, 7 July 1970; "Negro Businessman Bitter over Looting," Asbury Park Evening Press, 8 July 1970; Prucia Bruscell, "Demands Not Met, Negroes Maintain,” Asbury Park Evening Press, 8 July 1970.

${ }^{40}$ On arson as protest and the targeting of white businesses, see Gilje, Rioting in America, 159-60; Fogelson, Violence as Protest, 90-94. For the difficulty of proving that white businesses were targeted, see Alison Isenberg, Downtown America: A History of the Place and the People Who Made It (Chicago: University of Chicago Press, 2004), 231-38. John Needham, “In Asbury Park: Soul Paid for Some," Chicago Daily Defender, 8 July 1970.
} 
hail of stones, leaving their hoses in the street. Afterward, an open hydrant flooded the first floors of shops and homes along the avenue. ${ }^{41}$

By 4 p.m., the fires caused town officials to ask Jersey Central Power \& Light to cut off power to a six-block area around Springwood Avenue. Although firefighters had brought the fires under control by 7 p.m., electricity was still not restored to the area by nightfall—some two hours later-and police pulled all personnel from the West Side as darkness fell. As Flanagan explained, "We feared that in the dark it would lead to mass slaughter on both sides." Rather than patrol the darkened West Side, officials decided to cordon it off and leave the residents, most of whom were law-abiding throughout, to their fate. For the rest of the night, police only entered the area to respond to "emergencies." This sealing off of the West Side demonstrates that segregation was more than a means by which whites contained African Americans economically, socially, and politically. It was also a means by which whites exercised police control of the black community. ${ }^{42}$

In other developments on July 6, the Central Jersey and Pennsylvania railroads eliminated their stops at Asbury Park after rioters threw rocks and bottles at the trains. The police made more than 105 arrests for looting, curfew violation, and carrying concealed weapons. But by 2 a.m., the streets were again quiet, and by 4 a.m., police from neighboring municipalities were sent home. The Times reported that forty people, including six policemen, had been injured, though none seriously. But property damage was estimated at $\$ 2$ million. Eight buildings in the West Side were heavily damaged or destroyed, and the fire chief's car had

\footnotetext{
41 “Asbury Park Beset Again by Violence in Spite of Curfew," New York Times, 7 July 1970.

${ }^{42}$ Wheeling, "State, Local Policemen Guard West Side Ruins," Asbury Park Evening Press, 7 July 1970. Segregation has historically served as a tool of police control of African Americans during riots. Notable examples include Detroit in 1943 when police isolated the black district, and also Chicago in 1919 where police exercised authority only in the black precincts of the city to arrest any African Americans who attacked white "invaders" of the community. This arrangement permitted whites to freely assault any blacks who ventured into white neighborhoods. See Gilje, Rioting in America, 157-58 and Chicago Commission on Race Relations, The Negro in Chicago: A Study of Race Relations and a Race Riot (Chicago: University of Chicago Press, 1922), 595-602.
} 
been burned. The escalation of arson and the presence of the state police also brought the first television coverage. ${ }^{43}$

The third day also saw the emergence of an attempt within the African-American community to resolve matters peacefully. The New York Times reported a "sharp division of opinion" among blacks in the city over how to deal with longstanding grievances. This split was largely generational and may also have reflected class differences. As the Times described it, the divide was between African Americans "who operate businesses, engage in the professions or hold skilled jobs and young activists who are pressing for a faster pace of improvement of housing and recreation." The first attempt of the older generation of leaders to move back to non-violent means of redress took place in the early evening of July 6 when Ermon K. Jones called a meeting at the West Side Community Center. Jones said he hoped to find ways to bring calm. But with the West Side in flames, the meeting broke up in just twenty minutes. ${ }^{44}$

Officials seemed perplexed about the cause of the unrest. Mayor Mattice claimed that "the disorders were sparked by dissatisfaction with the leadership of the West Side Community Center" but offered no further explanation. Perhaps he had read Jones's earlier statements and found in them a way to shift blame onto the local African-American leadership. The mayor would later disavow this statement altogether. For his part, Chief Smith adopted a conciliatory approach, close to that of Matthews and Jones. "The youths on the West Side have the same

\footnotetext{
${ }^{43}$ Wheeling, "State, Local Policemen Guard West Side Ruins," Asbury Park Evening Press, 7 July 1970; "Asbury Park Beset Again," New York Times, 7 July 1970. It is difficult to assess the affect of television coverage without access to all of the broadcast tapes, which were not available for review. The Asbury Park Evening Press ran an article that claimed local residents were generally disgusted with the television news coverage, which they said was inaccurate and sensational. The state police arrested ABC newsman Dell Wade after he refused to identify himself and verbally abused the police. Wade claimed the police arrested him because he was reporting into his tape recorder that he saw a trooper push a man through a plate-glass window. A wire service reporter, however, said that the trooper actually pushed the man back into a doorway to prevent him from being injured. Of course, newspaper criticism of television reporting might also be seen as self-serving. See "TV Coverage of Disorders Spurs Disgust from Many," Asbury Park Evening Press, 9 July 1970.

44 “Asbury Park Beset Again," New York Times, 7 July 1970; Wheeling, "State, Local Policemen Guard West Side Ruins,” Asbury Park Evening Press, 7 July 1970.
} 
beefs as youths in other municipalities—no jobs, little recreation and poor housing," he told the Press. "When you talk with them, they can almost bring you around to their way of thinking."

Smith's comments reflect his anomalous position in the wake of the rioting. The New York Times hardly ever mentioned his name without adding that he was "a Negro."46 On the one hand, as chief of police, Smith represented the forces of order, an order that other leaders in the black community claimed was inherently racist and unjust. On the other hand, Smith was also a leader of the African-American community-albeit of the older generation. In this latter capacity, he could "almost" be brought around to the position of the youths on the street.

Smith's family had lived in the segregated West Side since he was two, and he had attended the city's segregated schools. Although he later said the beachfront was always important to him growing up, it too had been segregated. As he explained himself, "We were down at the lower end of the beach, just before you get to Ocean Grove, and there was a sewer pipe that ran through there, but that was the only beach that we could use." ${ }^{\prime 47}$

Smith's success came through playing by the rules, not by bucking them, even though the rules were segregation, discrimination, and racism. His own experience seems to have convinced him that change, though incrementally slow, was possible. As he told a local Kiwanis Club just two years before the riots, "self-discipline and moral decency must be brought back into style to combat the rising tide of crime. If you have youngsters, take the time to develop in them a sense of personal responsibility and understanding of the importance of maintaining high moral standards, and of the constant devotion to religious principles and of the necessity for

\footnotetext{
${ }^{45}$ Wheeling, "State, Local Policemen Guard West Side Ruins," Asbury Park Evening Press, 7 July 1970.

46 "Asbury Park Beset Again," New York Times, 7 July 1970; "Curfew is Ended for Asbury Park," New York Times, 11 July 1970; "Troopers a Major Force at Asbury Park," New York Times, 9 July 1970; "Calm Police Official: Thomas Sydney Smith," New York Times, 8 July 1970.

${ }^{47}$ June West, "Interview with Thomas S. Smith," 15 Dec. 1999, Remembering the $20^{\text {th }}$ Century: An Oral History of Monmouth County, under the auspices of the Monmouth County Library Headquarters, http://www.visitmonmouth.com/oralhistory/bios/SmithThomas.htm.
} 
fostering a deep and abiding love of our country." Smith had been a star football player at Asbury Park High School and again at Howard University. He left the university without taking a degree and returned to Asbury Park where he became a patrolman in 1941. After an interruption in his career for service in the army, he returned to the police department. He made detective in 1953 and captain four years later. In 1959, he took the exam for chief, and though he scored higher than his white rival, he did not receive the appointment. Smith, though, was a patient man, and when a new opportunity arose in 1967, he was appointed acting chief and finally chief a year later. ${ }^{48}$

In the summer of 1970, Smith admitted to finding himself "a little confused." "If you had told me 20 or 30 years ago this would happen, I would have said 'No,", he told the Times, "but there has been a change of thinking. Our kids are seeking identity. They are reading, they are thinking, they are exposed to a lot more." ${ }^{49}$ Part of the reason Smith was a little confused is that the youth on the streets were the product of experiences far different from his own. Although Smith had lived through the Great Depression, World War II, segregation, discrimination, and racism, as well as the urban "race riots" of the 1940s, he was the product of the pre-television age. The civil unrest of the late 1960s, due to television coverage, seemed more immediately experienced to Americans than the riots of the 1940s. The Civil Rights Movement, Dr. King's murder, and the Black Revolt were seared into the collective memory of all Americans by 1970. And then there was the Vietnam War, which convinced many Americans that playing by the rules could get you brought home in a body bag for no readily understandable reason.

On July 7, black leaders from the West Side presented the mayor and council with twenty-one demands. Among these were more industry for year-round employment, the

\footnotetext{
48 June West, "Interview with Thomas S. Smith;" “Calm Police Official” New York Times, 8 July 1970.

49 “Calm Police Official,” New York Times, 8 July 1970.
} 
completion of the urban renewal program, and the immediate hiring of one hundred teens in summer jobs. Other demands included the firing of Municipal Court Judge Eugene Capibianco, who had a reputation in the West Side for being insensitive to the black community; amnesty for those arrested during the unrest, and the immediate removal of the state police and police from neighboring municipalities. A number of other demands were typical of those black leaders in urban communities had made during the 1960s, such as the establishment of a civilian police review board, more police protection in order to combat the narcotics trade, rent control, and attention to the problems of public health and recreation. ${ }^{50}$

Willie Hamm, an assistant administrator at Rutgers University who lived in the West Side, read the demands to Mayor Mattice and councilmen Edward R. English and Ascenzio R. Albarelli at an early morning meeting at the Monmouth Community Action Program offices at Springwood and Main. The Press described the meeting as "stormy," and Hamm accused the police of brutality. ${ }^{51}$ With the exception of hiring some teens for summer jobs, granting amnesty to those on the municipal docket, and sending the state police home, it is not clear that the municipal government had much authority to immediately meet the demands. But Hamm was clearly not satisfied with explanations. "This doesn't take any more time or any more decision making," he told the mayor. "It takes an answer. You have the blame for all this on your shoulders. It didn't take a formal action of the Council to bring outside firemen and police into this city." $" 52$

Hamm had shifted the blame for the disorders onto the mayor and council. As far as he was concerned, whatever might occur from this time forward was the responsibility of city

\footnotetext{
50 "20 Demands by Negroes Considered by City Council," Asbury Park Evening Press, 7 July 1970; Buscell, "Demands Not Met," Asbury Park Evening Press, 8 July 1970; Johnson, “Asbury Park Blacks List 21 Demands," New York Times, 8 July 1970.

51 “20 Demands," Asbury Park Evening Press, 7 July 1970.

52 Ibid.
} 
officials. Whatever the intention of the West Side leaders, the demands had the character of an ultimatum. At least this was how some on the street understood them. "If they don't give us the demands, it's going to be hell," twenty-one-year-old Ronald Harris told the Times. "I've been to Vietnam and I don't give a damn anymore."53

In the early afternoon, about one hundred West Side residents gathered at the Monmouth Community Action Program (MCAP) offices to hear the mayor's response. During another stormy session, Mattice acceded to only one of the demands-Hamm's appointment to the Board of Education. The meeting left many residents "shaking their heads." The demand for amnesty was particularly contentious. Donald Hammary argued that many of those arrested had been out on the streets trying to keep the peace. But city attorney Norman Mesnikoff contended that the city had no power to withdraw charges. In the end, Mattice agreed to appoint two black representatives to accompany Mesnikoff to the county seat in Freehold to ask Judge Elvin Simmill to release some of those held in the county jail. Simmill agreed to release several persons but refused to dismiss the charges against more than ninety others. ${ }^{54}$

There was little movement on the West Side leaders' other complaints. Hamm again pressed the mayor to dismiss Judge Capibianco, but Mattice said the council had no power to do so. "You know the judge is the core of this thing," Hamm told the mayor. "You can get rid of him if you want to." City officials told the West Side residents they favored the resignation of Housing Authority Director John Lumley and also the completion of the urban renewal program but made no promises. The residents noted, forlornly, that the demolition of substandard

\footnotetext{
53 Johnson, “Asbury Park Blacks List 21 Demands,” New York Times, 8 July 1970.

54 Buscell, "Demands Not Met," Asbury Park Evening Press, 8 July 1970.
} 
buildings had begun in 1958 but that "no new construction had begun." The mayor also tabled any decision on the creation of a civilian police review board. ${ }^{55}$

Although it opened a dialogue, the meeting ended inconclusively at 2 p.m. "I couldn't say any of the demands were resolved," Mattice told the Press upon leaving. "All I can say is we gave them answers." MCAP director Joseph F. Taylor, trying to put the best face on it, said the meeting was "healthy," though the community leaders were disappointed with the lack of progress. But perhaps MCAP's deputy director Wilbert C. Russell had the most realistic view. "I'm afraid the mayor and Council are depending on the state police to protect them," he told the Press. "If they do nothing about these demands, when the police leave, there's going to be more trouble. And this time, they're going east [into the largely white-owned business district]." ${ }^{, 56}$

To this point, city officials had said little about the cause of the disorders, but upon leaving the meeting, Mattice revealed himself to the Times. "You see that," he said, directing the attention of the reporter to a dozen or so black teenagers standing around on Main Street. "That's the reason. It's young people like that." The words, in spite of their calculated ambiguity, dripped with disdain. Joseph M. McCarthy, the chief of police of Middletown Township, a largely white suburb that had sent a contingent of police to Asbury, went even further. Although he said any injustices done to the people of the West Side ought to be rectified, McCarthy described the rioters as "out of towners, junkies, and criminals."

\footnotetext{
${ }^{55}$ Ibid.

${ }^{56}$ Buscell, "Demands Not Met," Asbury Park Evening Press, 8 July 1970.

${ }^{57}$ Johnson, "Asbury Park Blacks List 21 Demands," New York Times, 8 July 1970; "Middletown's Chief Tells of Facing Fire by Snipers," Asbury Park Evening Press, 8 July 1970. McCarthy was trotting out the "riffraff theory," which held that the trouble was all the work of a small percentage of the black population composed of riffraff and outside agitators. As Fogelson has argued, the riffraff theory was highly reassuring to whites, who could take comfort in the idea that the majority of blacks opposed violent street action. He also notes that the adherents of the riffraff theory "have not offered solid supporting evidence" of its validity. See Fogelson, Violence as Protest, 28-51 and Isenberg, Downtown America, 233.
} 
It did not take long for Russell's prediction to come true. The youth in the street waited to hear the results of the meeting with the mayor but not for the state police to leave. By three o'clock in the afternoon, rioting erupted again. Police reported that the peak of the disorders came at about 4:30 p.m. when hundreds of persons were "out of control" in the West Side. This time the crowd made a concerted effort to break through police barricades and into the white business and residential areas along Main Street and farther east. If the teens had not specifically targeted white businesses for destruction the day before, they did so now. As some of the teens broke through onto Main Street, a young girl in the crowd shouted, "Hey, they're going eastthey're going east. I hope they burn it down." The crowd briefly surged into the east side and began breaking windows and looting before police drove them back across the railroad tracks and into the West Side. It was then that the shooting began. The state police claimed they fired over the heads of the demonstrators to drive them back and to stop them from throwing Molotov cocktails, rocks, and bottles. Middletown's police chief also claimed that his officers took sniper fire. But, in spite of these claims, local hospitals treated forty-six people, none of them police, for gunshot wounds. Four of those shot were reported in critical condition. In all, more than seventy persons were injured in Tuesday's unrest, and police made fifty arrests. Among the injured were nine state troopers, five of whom required hospital treatment. ${ }^{58}$

The use of force seems to have been decisive. Police were able to disperse the remaining crowd by 6 p.m. and were patrolling the West Side by nightfall along with a citizen's patrol of African-American youths and community leaders in red armbands. On Wednesday the city was quiet, and United Press International reported that "Springwood Ave., on the west side, lined

\footnotetext{
${ }^{58}$ It might be argued that the police were within their rights to fire on the rioters who were throwing Molotov cocktails at them, but it is difficult to assess at this remove the extent to which the rioters resorted to Molotov cocktails and exactly how they were used. John Wheeling, "Shooting Erupts, 56 Are Hit" and "Tumult and Shouting Put Damper on City Business," Asbury Park Evening Press, 8 July 1970.
} 
with wrecks of buildings devastated by burning, looting and smashing, was almost deserted." The "Asbury Park riots" were over. Mayor Mattice breathed a sigh of relief. "We've been very, very fortunate it's stayed where it has. Our business area hasn't been affected at all." For Mattice it was as if the seventy-five businesses in the West Side that had been damaged or destroyed had never existed. It was just as the Rev. Matthews had said: a "general concern for the West Side on the part of the politicians was lacking." One wonders what the mayor had learned as his city burned..$^{59}$

But what is perhaps more interesting about Asbury Park's "troubles" is their evolution over four days from teenage misbehavior to something much more organized and purposeful. Many of the youths on the street seem to have evolved from teenagers with little more to do than throw rocks and bottles at one another to something like freedom fighters. Evidence for this evolution comes from what scholars have called "targeting," which demonstrates rational intent. On the first day, teens attacked cars without regard to whether the occupants were white or black, but by the fourth day, they seem to have specifically targeted white motorists. Moreover, though the arson of the third day seems to have damaged more black businesses than white, day four witnessed a deliberate effort to destroy the white business district east of Main Street. ${ }^{60}$

It is also instructive that on the last day of unrest the youths did not congregate along the barricades at Main Street and Springwood until they had first learned of Mayor Mattice's answers to the twenty-one demands. It is clear from their actions that most believed they were now fighting for a political purpose and saw themselves as part of the Black Revolt so fresh in everyone's collective memory. This would explain the appearance of a young man waving a Black Liberation flag in the middle of Main Street as the police massed on Tuesday afternoon, as

\footnotetext{
${ }^{59}$ Paul L. Montgomery, "46 Shot in Rioting at Asbury Park, Curfew Imposed,” New York Times, 8 July 1970; Robert Slater, “Asbury Blacks Meet: Blast Brutality,” Chicago Daily Defender, 9 July 1970.

${ }^{60}$ On "targeting," see n. 39 above; Wheeling, "Shootings Erupt," Asbury Park Evening Press, 8 July 1970.
} 
well as the actions of two young girls who "joined him and raised clenched fists," the symbol of Black Power. This transformation of the youth seems to have been largely the work of West Side community leaders such as Ermon K. Jones, Donald Hammary, and Willie Hamm who gave voice to the grievances of the ghetto and a rationale for the uprising. ${ }^{61}$

On Tuesday evening, the first editorial comment appeared in the Asbury Park Evening Press. This editorial, written prior to the unrest on Tuesday, emphasized the destructiveness and irrationality of the disorders. "Irrational disturbances," it said, "promote only tensions that strew debris across the road to progress." The Press recognized two different types of participants in "riotous outbreaks," neither of whom was able to reasonably articulate grievances. The first "become involved only because of the excitement and a perverse satisfaction in destruction. This group recognizes no grievance; it promotes no cause." The second type "sense that they have a grievance, although they are not always able to define it."62

Ignoring its own coverage of the debate over the demands, the Press claimed that “Asbury Park [had] done reasonably well in improving the lot of its less fortunate citizens." As evidence, the editorialist pointed weakly to the "Monmouth Community Pool, which was built with private contributions" and a new middle school that was close to completion. While recognizing that the city still had "room for improvement," the editorial made no mention of the widespread unemployment among West Side youth, the segregation of the community, the stalled urban renewal program, or the slum conditions that had prevailed since at least $1938 .{ }^{63}$

In a follow-up editorial the next day, the Press argued that rebuilding the city required "an erasure of several misconceptions." First, it noted that, contrary to the popular impression, only a small portion of the city's black population had taken any part in the violence. The

\footnotetext{
61 "Tumult and Shouting Put Damper on City Business," Asbury Park Evening Press, 8 July 1970.

62 "Violence Never Heals," Asbury Park Evening Press, 7 July 1970.

${ }^{63}$ Ibid.
} 
editorialist also hoped "to scotch the notion that the police are an oppressive force to be subjected to scorn" and rejected the view that "all demands submitted to the City Council were either valid or without merit." Specifically, the Press rejected the demand that the municipal judge be ousted without specific charges and said there was no validity to the demand that amnesty should be granted to persons arrested during the disorders. On the other hand, the paper noted that progress on urban renewal had been "scandalously slow" and "should be speeded toward conclusion." It also called for more recreation facilities in the West Side, "a vigorous attack on narcotics pushers," and improved housing. ${ }^{64}$

Although the Press's second editorial gave some slight recognition to the neglect the West Side had suffered for decades, the paper's overall assessment was that the disturbances were the work of an irrational mob bent on little more than destruction. And indeed, this was the impression Mayor Mattice gave to the media when he told reporters that he was convinced "outside forces" were involved. He would not, however, say who the outsiders were because, he claimed, to do so would "betray confidences he [had] with informers." The mayor's assessment, though, is not borne out by news reports. ${ }^{65}$

In what seems to have been a direct response to the first Press editorial, the New York Times portrayed the action on the street as an understandable reaction to unjustified neglect and oppression, particularly given the disinclination of local leaders to improve conditions for African Americans through the normal operation of politics. To the Times, the benign attitude of the police was also far from clear. It noted that when the residents of the West Side, "poured out of that ghetto, and across the tracks of the Penn Central to invade the business section of the town, hurling bricks, bottles, and fire bombs," they "were met by police and state troopers, who

\footnotetext{
64 “Entire City Suffers," Asbury Park Evening Press, 8 July 1970.

65 "Riot has Mattice on Run While Handling Both Jobs," Asbury Park Evening Press, 11 July 1970.
} 
assert that they fired their weapons into the air; but dozens of blacks were gunshot victims."66 This July 9 editorial clearly built on the Times' reporting, which sometimes described the youths on the street heroically as "freedom fighters."

The Asbury Park riots also prompted an editorial in the Chicago Daily Defender, the nation's most important African-American newspaper, which had begun its coverage on July 8 by reprinting reports from UPI. The Defender argued that "joblessness and police brutality were at the core" of the riots. It linked what happened in Asbury to a nationwide pattern of police mistreatment of black youth, noting that "officials of many municipalities have initiated no steps insuring the prevention of irresponsible police behavior." The Defender, ignoring what actually sparked the disturbances in Asbury, warned that officials across the country "are sadly mistaken if they think black boys already steaming with anger over their job status will let the police push them around, whatever may be the excuse." 68

One question that arose in the wake of the troubles in Asbury was: Does violence work? The New York Times broached this subject in its July 9 editorial, pointedly disagreeing with the Press' assessment that violence results only in destruction:

The cruelest part of this tragic explosion is that if, belatedly, Asbury Park officials and others at the state level and Federal level now begin to minister to the town's ailments, it will demonstrate that violence pays. ${ }^{69}$

At the very least, the violence had finally brought attention to the very real problems in the West Side. In the days following the disorders, U.S. Rep. James J. Howard and Gov. William T. Cahill toured the ruins. Cahill said he would ask President Nixon to declare the city a disaster area, an appeal that was ultimately unsuccessful, in spite of garnering support from Roy Wilkins,

\footnotetext{
66 "Violence in Asbury Park," New York Times, 9 July 1970.

67 "Violence in Asbury Park," New York Times, 9 July 1970; Paul L. Montgomery, "The Hot Summer Comes to Asbury Park," New York Times, 12 July 1970.

68 “Asbury Park Riots," Chicago Daily Defender, 16 July 1970.

69 "Violence in Asbury Park," New York Times, 9 July 1970.
} 
the executive director of the NAACP. Still, it is difficult to see how peaceful complaints could have attracted such attention. ${ }^{70}$

But while violent street action focused the attention of the establishment and the public on the ills of Asbury Park, the violence could not last forever. Once it ended, the media spotlight moved elsewhere, and Asbury fell back into the torpor of neglect. By 1990 most of the city was in decay, and even the once vibrant boardwalk was largely abandoned. On September 27, 1994, a joint committee of the New Jersey Senate and Assembly convened a "focus group" to study the seaside resort's malaise. Among the problems the participants cited were high unemployment, high crime and taxes, image, deteriorating infrastructure, and poverty. Residents and civic leaders asked for increased police protection, more jobs, a reduction in narcotics trafficking, more educational resources, the redevelopment of the ocean front, and the rehabilitation of the shopping district. ${ }^{71}$

By 1990 , the population had declined to 17,000 . A greater percentage, though, was black, and since 1970 there had been a rapid increase in the Hispanic population. The economic decline of the city had already begun before the "troubles," but the civil unrest seems to have accelerated white flight and led to a decline in the city's middle class. In the early seventies, the city’s shopping district had also faced a challenge from new suburban shopping malls. ${ }^{72}$

The poor economy increased the city's woes. The city planning director told the joint committee that the percent of the population on public assistance had risen from seventeen

\footnotetext{
${ }^{70}$ Walter H. Waggoner, "U.S. Aid Sought for Asbury Park," New York Times, 10 July 1970; Gary Deckelnick, "West Side Calm for $2^{\text {nd }}$ Night," Asbury Park Evening Press, 10 July 1970; "Urge Nixon to Aid Asbury Park," Chicago Daily Defender, 25 July 1970. U.S. Federal Emergency Management Agency, 1970 Federal Disaster Declarations, http://www.fema.gov/disasters/grid/year/1970?field_disaster_type_term_tid_1=All. For the success of rioting in garnering attention to the problems of the ghetto, see Button, Black Violence, 158-60.

${ }^{71}$ New Jersey Legislature, Focus Group, September 27, 1994, The United States Post Office, Asbury Park, New Jersey, 7, 9-10.

${ }^{72}$ U.S. Census 2000, Table DP 1. Profile of General Demographic Characteristics, Geographic Area: Asbury Park city, New Jersey.
} 
percent in 1980 to twenty-two percent by 1990 . The unemployment rate in town was twelve percent. The city had also lost much of its tax base. Fifty-five percent of the properties in Asbury Park were tax exempt. The town had also become home to a large number of exconvicts, parolees, and the mentally ill, who found cheap accommodations in the city's rundown boardinghouses. Moreover, absentee landlords used their political muscle to prevent the city from enacting an adequate housing code. Finally, as Deputy Mayor Carl Williams noted, "25 percent of the juvenile crime for the whole county comes out of Asbury Park. If you look east of Main Street, there are no alternatives for the kids; there is not a swing; there is not a sliding board." On the West Side, he said, the equipment was "old and dangerous."73

Thomas S. Smith, by then a Republican assemblyman, participated in the focus group. He looked back somewhat wistfully to an earlier time. "I think what we're overlooking is the history of Asbury Park. Many years ago, Asbury Park was the commercial hub of the county. Then the malls came along and hurt us there. We had a great number of what we called locked factories where pieces came in and were assembled. . They're all gone. But most of all, we were known as a resort city. In the summertime, we would have maybe 200,000 or 300,000 people here in this small, mile-square town, using our beaches and our hotels. At that time, we had about ten hotels that were good hotels. They no longer exist." 74

Smith did not mention that in the city's heyday, segregation prevented him, a city resident, from using Asbury's world-class beach except where the town sewer pipe emptied into the sea. He had had to walk ten miles to use a decent integrated beach in Belmar. During both the focus group hearing and the public hearing of the Senate Urban Policy and Planning

\footnotetext{
${ }^{73}$ New Jersey Legislature, Focus Group, 19, 23, 31, 36, 47; U.S. Census 2000, Table DP 1. Profile of General Demographic Characteristics, Geographic Area: Asbury Park city, New Jersey.

${ }^{74}$ New Jersey Legislature, Focus Group, 46-47.
} 
Committee held in the city council chambers later that evening, no one mentioned the "troubles" of July 1970 either. It was as if they had never happened. ${ }^{75}$

Daniel Weeks is an assistant research professor at the Thomas A. Edison Papers, Rutgers University. He is the author of Not for Filthy Lucre's Sake: Richard Saltar and the Antiproprietary Movement in East New Jersey, 1665-1707, a history of colonial New Jersey politics, which Lehigh University Press published in 2001. Weeks earned a Ph.D. in American history from Rutgers University in 2012. He also holds an M.A. in history from Monmouth University (1995) and a B.A. in American history from Washington \& Lee University (1980). He lives in Eatontown, N.J.

\footnotetext{
${ }^{75}$ New Jersey Senate Urban Policy and Planning Committee, Public Hearing, Urban Problems in Asbury Park,
} Asbury Park Municipal Building, September 27, 1994. 